\title{
ПИТАННЯ ЗАБЕЗПЕЧЕННЯ ОХОРОНИ ПРАВ І СВОБОД ЛЮДИНИ, ПРОТИДІЇ ЗЛОЧИННОСТІ, ПІДТРИМАННЯ ПУБЛІЧНОЇ БЕЗПЕКИ ТА ПОРЯДКУ ПІДРОЗДІЛАМИ НАЦІОНАЛЬНОЇ ПОЛІЦІЇ УКРАЇНИ В ЗОНІ ПРОВЕДЕННЯ ОПЕРАЦІї ОБ'ЄДНАНИХ СИЛ
}

Колесник С. П.

у статті проаналізовано окремі проблемні питання щодо забезпечення охорони прав і свобод людини, протидії злочинності, підтримання публічної безпеки і порядку на території проведення Операції об'єднаних сил. Стаття $\epsilon$ актуальною, адже оперативна ситуація в Україні загалом та на території проведення Операції об'єднаних сил зокрема постійно змінюється. Ці питання набувають актуальності у зв'язку з постійною міграцією населення, унеможливленням проведення оперативно-розшукових дій на окупованій території, суворою необхідністю безперервного контролю над витоком зброї та боєприпасів із зони конфлікту на мирну територію держави та багатьма іншими нагальними проблемами, які виникли в період агресії проти України.

Ключові слова: Операція об'єднаних сил, Національна поліція України, конфлікт, злочинність, правопорядок, закон.

В статье проанализированы отдельные проблемные вопросы по обеспечению охраны прав и свобод человека, противодействию преступности, поддержанию публичной безопасности и порядка на территории проведения Операции объединенных сил. Статья актуальна, так как оперативная ситуация в Украине вообще и на территории проведения Операции объединенных сил в частности постоянно меняется. Эти вопросы приобретают актуальность в связи с постоянной миграцией населения, невозможностью проведения оперативно-разыскных действий на оккупированной территории, строгой необходимостью непрерывного контроля за утечкой оружия и боеприпасов из зоны конфликта на мирную территорию государства и многими другими неотложными проблемами, которые возникли в период агрессии против Украины.

Ключевые слова: Операция объединенных сил, Национальная полиция Украины, конфликт, преступность, правопорядок, закон.

Law enforcement issues always remain a priority in ensuring human, society and state life. Without exaggeration, it can be argued that ensuring law and order serves not only one of the most important duties of the state to the citizens, but also the very condition of existence of the state, acting as the basis of its sovereignty and territorial integrity, its economic and information security.

The article analyzes some problematic issues related to the protection of human rights and freedoms, combating crime, maintaining public security and order in the territory of the Joint Forces Operation. The article is relevant today as the operational situation in Ukraine as a whole and in the territory of the Joint Forces Operation is constantly changing. These issues become relevant in connection with the constant migration of the population; impossibility of carrying out operative-search actions in the occupied territory; the urgent need

Колесник С. П., 2019 for continuous control of the leakage of arms and ammunition from the conflict zone into the peaceful territory of the state, and many other pressing problems that arose during the period of aggression against Ukraine. The state of personal police security in the course of performance of operational and service tasks was analyzed. Namely, the advisability of improving performance models of police training based on international experience was considered, with the aim of prevention of injuries and death on duty, raising the appropriate level of theoretical knowledge and its skillful use with practical activity. Many countries have passed reforms or are in the process of reforms including reforms of law enforcement and their experience can be useful in Ukraine. Indeed, international experience is important, since it allows to see the effectiveness or ineffectiveness of the implementation of elements of police training in other countries in performing operational and service tasks, ensures personal security while on duty. The effectiveness of police performance of operational and service tasks depends on the possession of personal safety techniques in typical and extreme situations, in the event of combating illegal actions, and in the case of accidents and other emergencies.

Key words: Joint Operations, National Police of Ukraine, conflict, crime, law and order, law.

Постановка проблеми та її актуальність. Питання, пов'язані з забезпеченням правопорядку, завжди були пріоритетними у забезпеченні життєдіяльності людини, суспільства і держави. Без перебільшення можна стверджувати, що забезпечення правопорядку $\epsilon$ не лише одним із найважливіших обов'язків держави перед громадянами, а й самою умовою існування держави, виступаючи основою іï суверенітету і територіальної цілісності, її економічної та інформаційної безпеки.

Метою статті $\epsilon$ розгляд окремих проблемних питань щодо забезпечення охорониправ ісвобод людини, протидії злочинності, підтримання публічної безпеки і порядку на території проведення Операції об'єднаних сил.

Виклад основного матеріалу. Оперативна ситуація в Україні загалом та на території проведення Операції об'єднаних сил (далі - ООС) зокрема постійно змінюється, тому питання, що стосуються забезпечення охорони прав і свобод людини, протидії злочинності, підтримання публічної безпеки і порядку, у тому числі на території ООС, не втрачають, а набувають актуальності.

Постійна міграція населення, унеможливлення проведення оперативно-розшукових дій на окупованій території, сувора необхідність безперервного контролю над витоком зброї та боєприпасів із зони конфлікту на мирну територію держави та багато інших нагальних проблем, які виникли в період агресії проти України, змусили законодавців і науковців різних галузей права знаходити нові методи та форми діяльності правоохоронних органів в умовах, що склались у цей період. 
Згідно зі ст. 8 Закону України «Про особливості державної політики із забезпечення державного суверенітету України на тимчасово окупованих територіях у Донецькій та Луганській областях» [1] Національну поліцію віднесено до суб'єктів забезпечення національної безпеки і оборони, відсічі і стримування збройної агресії у Донецькій та Луганській областях. Серед інших правоохоронних органів саме поліція виконує провідну роль щодо забезпечення правопорядку в зоні ООС. Такий висновок випливає, зокрема, з визначення поняття та завдань, які покладено на поліцію (статті 1, 2 Закону України «Про Національну поліцію України» [2]. Так, завданням поліції $\epsilon$ надання поліцейських послуг у таких сферах: 1) забезпечення публічної безпеки i порядку; 2) охорони прав і свобод людини, а також інтересів суспільства і держави; 3) протидії злочинності; 4) надання в межах, визначених законом, послуг з допомоги особам, які з особистих, економічних, соціальних причин або внаслідок надзвичайних ситуацій потребують такої допомоги.

Виконуючи покладені на неї обов'язки щодо підтримання правопорядку й законності з метою дотримання конституційних прав і свобод людини і принципів діяльності, Національна поліція відповідно до ст. ст. 7, 37 Закону України «Про Національну поліцію України» під час виконання своїх завдань забезпечує дотримання прав і свобод людини, гарантованих Конституцією та законами України, а також міжнародними договорами України, згода на обов'язковість яких надана Верховною Радою України, а також сприяє їх реалізації [2].

Обмеження прав і свобод людини допускається виключно на підставах та в порядку, визначених Конституцією і законами України, за нагальної необхідності i в обсязі, необхідному для виконання завдань поліції у зоні проведення ООС. Здійснення заходів, що обмежують права та свободи людини, має бути негайно припинене, якщо мета застосування таких заходів досягнута або немає необхідності подальшого їх застосування. При цьому конкретні права і свободи громадян згідно із загальним правилом мають такі ж конкретні підстави їх обмеження. 3 огляду на це не може бути обмежене, скажімо, право на свободу світогляду й віросповідання необхідністю з'ясувати істину під час розслідування кримінальної справи, а право на недоторканність житла - необхідністю запобігти розголошенню інформації, одержаної конфіденційно. Інші, крім зазначених вище, обмеження прав і свобод можуть встановлюватися лише в умовах воєнного або надзвичайного стану, при проведені ООС та завжди мають визначений тимчасовий характер.

Поліція здійснює свою діяльність на основі дотримання та поваги прав і свобод людини та громадянина. Діяльність, що обмежує права і свободи громадян, негайно припиняється, якщо досягнута законна мета або 3'ясувалося, що ця мета не може або не повинна досягатися шляхом обмеження прав і свобод громадян. У всіх випадках обмеження прав особистості припиняється після досягнення мети обмеження відповідного права.

Відповідно до статті 39 Конституції України проголошується право громадян на проведення мирних масових заходів у законодавчо визначеному порядку, відповідно до якого громадяни мають право збиратися мирно, без зброї і проводити збори, мітинги, походи i демонстрації, про проведення яких завчасно мають сповістити органи виконавчої влади чи органи місцевого самоврядування. У ч. 2 цієї ж статті вказується, що обмеження реалізації цього права може встановлюватися судом відповідно до закону і лише в інтересах національної безпеки та громадського порядку з метою запобігання заворушенням чи злочинам, для охорони здоров' я населення або для захисту прав і свобод інших людей. Зазначимо, що масові заходи - це заплановані або стихійно організовані заходи громадсько-політичного, релігійного, спортивного, культурно-видовищного характеру за участю значної кількості громадян, що проводяться з нагоди офіційних (державних), професійних, релігійних свят, пам'ятних дат, а також за ініціативою політичних партій, рухів, громадських об'єднань, релігійних конфесій (громад), окремих громадян, спортивних організацій, закладів культури тощо, в яких бере участь значна кількість осіб. Такі заходи спрямовані на реалізацію та захист прав та законних інтересів різної спрямованості.

Треба врахувати, що, з одного боку, масовий захід це найбільш доступна можливість задоволення потреб великої групи людей, а з іншого - це потенційна загроза життю і здоров'ю всіх учасників, вболівальників, глядачів, правоохоронців. Скупчення людей на обмеженій території за певних умов може стати поштовхом для різних групових порушень громадського порядку.

Пов'язано це з кількома факторами. Закритий простір підвищує небезпеку порушення правопорядку з боку групи людей, сформованої спонтанно або організовано. Зміна звичного ритму, а також динаміка подій може спровокувати випадки конфліктів між окремими громадянами чи їх певними групами. Забезпечення правопорядку на території проведення спеціальної операції об'єднаних сил додає своїх специфічних особливостей або загроз, які необхідно враховувати [5].

3 огляду на це під час масових заходів в зоні проведення ООС підрозділами Національної поліції України постійно розробляються та проводяться превентивні заходи щодо забезпечення правопорядку на території обслуговування. Водночас вживаються превентивні заходи, тобто оптимізація та збільшення маршрутів патрулювання у населених пунктах та районах, де проводяться масові заходи, проводяться роз'яснювальні роботи й відпрацювання населених пунктів, розташованих на лінії розмежування, а також фільтрування заходів на блокпостах, виявлення ДРГ.

Проаналізувавши накопичений досвід діяльності Національної поліції України під час забезпечення охорони публічної безпеки та порядку при проведенні масових заходів, констатуємо, що процес планування та проведення забезпечення правопорядку поділяється на три таких етапи:

- підготовчий, який починається з моменту отримання завдання 3 забезпечення правопорядку при проведенні масового заходу;

- виконавчий, який охоплює дії нарядів і керування ними безпосередньо під час проведення масового заходу;

- заключний, який здійснюється шляхом згортання сил і засобів та зосередження їх у призначених пунктах і підведення підсумків несення служби.

Найважливішим, на наш погляд, з точки зору забезпечення правопорядку під час проведення масових заходів в умовах ООС $\epsilon$ процес оцінки загроз та ризи- 
ків, який здійснюється та застосовується на кожному з перелічених етапів.

Загрозу коротко можна визначити як джерело реальної та потенційної шкоди (тобто будь-що, що може спричинити шкоду). Ризиком називають можливість настання шкоди. Отже, визначення того, які ризики виникнуть при забезпеченні правопорядку під час проведення масових заходів в умовах ООС, $є$ дуже суб'єктивним процесом. Поліцейські використовують свій досвід та знання для визначення рівня ризику, можливого в кожній конкретній ситуації.

Кожна із зазначених категорій повинна бути оцінена за 4-бальною шкалою. Після цього вживаються відповідні заходи на об'єктах, що мають підвищений рівень небезпеки. Ретельне оцінювання загроз має значний вплив на організацію та планування, а згодом і на успішне забезпечення громадського порядку під час проведення масових заходів, в тому числі і у зоні проведення Операції об'єднаних сил.

Урахування зазначених вище загроз під час планування діяльності правоохоронних органів $\epsilon$ необхідною передумовою забезпечення їх ефективної діяльності, результатом чого має стати створення надійного безпекового простору, недопущення порушення державного кордону України та мінімізація ймовірності вчинення терористичних актів на території нашої держави.

Що стосується питання протидії злочинності, то зазначимо, що у період проведення ООС збільшується вірогідність скоєння терористичних актів, диверсій на контрольованій території. Для запобігання вказаним ситуаціям необхідна чітко спланована взаємодія між всіма правоохоронними органами, прикордонною службою та Збройними силами України в єдиному інформаційному просторі. Одним зі шляхів вирішення вказаної проблеми може стати створення єдиної інформаційної бази.

Проблемним також $є$ те, що більшість осіб, які підозрюються у вчиненні злочинів, передбачених ст. 260 КК України, переховується на території, контрольованій терористичними організаціями, або в Російській Федерації, що унеможливлює затримання цих осіб та закінчення досудового розслідування. Оголошення ж вказаних осіб у міжнародний розшук неможливе, оскільки відповідно до статуту Міжнародної поліцейської організації «Інтерпол» та Європейської конвенції про видачу правопорушників учасники не передбачених законом збройних формувань вважаються такими, що вчинили політичне правопорушення або правопорушення, пов'язане з політичним правопорушенням, тобто такими, яких не оголошують у міжнародний розшук, а при затриманні не видають запитуваній Стороні. Пропонуємо створити єдину базу осіб, які $є$ учасниками кримінального процесу та які $\epsilon$ загрозою для публічної безпеки, з метою інформування слідчого про прибуття зазначених осіб на територію, підконтрольну українській владі.

Одним із нагальних проблемних питань забезпечення правопорядку в умовах проведення ООС залишається питання безпеки поліцейських. Згідно зі статтею 44 Закону України «Про Національну поліцію» поліцейський може застосовувати фізичну силу, у тому числі спеціальні прийоми боротьби (рукопашного бою), для забезпечення особистої безпеки та безпеки інших осіб, припинення правопорушення, для затримання особи, яка вчинила правопорушення, якщо застосування інших поліцейських заходів унеможливлює виконання поліцейських повноважень, покладених на нього законом [2]. Отже, на нормативному рівні закріплено норму щодо забезпечення особистої безпеки поліцейських під час виконання службових обов'язків [4]. Очевидно, що несення служби в зоні приведення ООС істотно відрізняється від виконання службових обов'язків у мирний час. Працівники Національної поліції України змушені дуже швидко пристосовуватись до специфіки несення служби, набувати навичок, які не зовсім властиві для правоохоронних підрозділів (загальновійськова підготовка, знання природи і тактики сучасного загальновійськового бою, саперна підготовка, топографічна підготовка, вміння користуватись зброєю, яка не стоїть на озброєнні в підрозділах Національної поліції України).

У процесі проведення ООС виникло питання підготовки поліцейських абсолютно іншої формації, які б ефективно виконували свої службові обов'язки. Проте чи не найважливішою проблемою можна вважати підготовку поліцейських за новими стандартами, які відрізняються від тих, що існували раніше. Однак успішне виконання поліцейськими оперативно-службових завдань за час проведення ООС багато в чому залежить і від умілого володіння прийомами особистої безпеки в типових та екстремальних ситуаціях. Структурну побудову підрозділів поліції треба здійснювати з урахуванням вивчення та впровадження передового зарубіжного досвіду та зі збереженням і вдосконаленням апробованих і ефективних вітчизняних практик застосування примусових поліцейських заходів, прийомів особистої безпеки в типових та екстремальних ситуаціях, а також у разі силового припинення протиправних проявів, у разі аварій, катастроф та інших надзвичайних ситуацій. Ця структура має відповідати загальносвітовому стандарту ефективної діяльності поліції.

Отже, реалії забезпечення особистої безпеки поліцейських під час виконання оперативно-службових завдань в рамках проведення ООС висвітлюють проблему, яка потребує особливої уваги. Сьогодні прийняття необхідного пакета підзаконних нормативно-правових актів з питань забезпечення особистої безпеки поліцейських, повного забезпечення підрозділів новітніми спеціальними засобами, вироблення чіткої концепції професійної підготовки поліцейських кадрів дасть змогу покращити захист поліцейського під час виконання оперативно-службових завдань у рамках проведення ООС. Розробка заходів щодо підвищення рівня особистої безпеки поліцейських із запозиченням зарубіжного досвіду уможливить вирішення теоретичних і практичних завдань службової діяльності.

Слід зазначити, що забезпечення правопорядку в умовах проведення ООС вимагає додаткових сил, засобів, а також прийняття організаційних, законодавчих та методичних рішень, спрямованих на нормативно-правову регламентацію взаємодії між Збройними силами України та НПУ й іншими правоохоронними органами, на забезпечення безпеки працівників правоохоронних органів, які працюють в умовах проведення ОOC, на недопущення терористичних актів та диверсій з боку членів диверсійно-розвідувальних груп НЗФ у спільній взаємодії всіх органів та структур, які функціонують з метою забезпечення цілісності кордону України, безпеки їі громадян та збереження публічного порядку. 


\section{Проблеми становлення правової демократичної держави}

Висновки. Підсумовуючи викладене вище, зазначимо, що сьогодні з боку держави не лише створюються важливі передумови для врегулювання збройного конфлікту, що триває на території Донецької та Луганської областей, а й звертається неабияка увага на створення належних умов для реалізації громадянами усіх наданих їм Конституцією України прав і свобод. 3 огляду на це важливого значення набуває створення умов для реалізації прав громадян саме під час врегулювання збройного конфлікту та забезпечення правопорядку під час проведення масових заходів.

\section{Література}

1. Про особливості державної політики із забезпечення державного суверенітету України на тимчасово окупованих територіях у Донецькій та Луганській областях : Закон України від 18 січня 2018 року № 2268-VIII. Відомості Верховної Ради України. 2018. № 10. Ст. 54.

2. Про Національну поліцію : Закон України від 02 липня 2015 року № 580-VIII. Відомості Верховної Ради України. 2015. № 40-41. Ст. 379.

3. Охріменко І.М. Світовий досвід підготовки кадрів поліції та його впровадження в Україні : матер. Між- нар. наук.-практ. конф., м. Дніпропетровськ, 17 березня 2016 р. Дніпропетровськ : Дніпроп. держ. ун-т внутр. справ, 2016. 556 с.

4. Тактичне керівництво та організація несення служби працівниками правоохоронних органів України в зоні проведення антитерористичної операції : навчальний посібник / ЛьвДУВС ; за заг. ред. Ю.Р. Йосипіва, С.М. Банаха, О.І. Тьорло, В.М. Синенького та ін. Львів, 2016. 136 с.

5. Аброськін В.В. Роль органів Національної поліції щодо забезпечення правопорядку в зоні проведення Операції об'єднаних сил. Забезпечення правопорядку на території проведення операції об'єднаних сил : зб. матеріалів доп. учасн. Всеукраїнського наук.-практ. Семінару, м. Маріуполь, 1 жовтня. 2018 р. Маріуполь, 2018. С. 85-94.

6. Підготовка та проведення спеціальних операцій у збройних конфліктах : навчальний посібник ЛьвДУВС / за заг. ред. Ю.Р. Иосипіва, А.В. Ярославського, О.І. Тьорло, І.Ю. Землянського, М.Д. Курляка, М.О. Московчук, В.М. Синенького та ін. Львів, 2016. 104 с.

Колесник С. П., здобувач кафедри тактико-спеціальної, вогневої та фізичної підготовки Одеського державного університету внутрішніх справ 